University of California, Hastings College of the Law UC Hastings Scholarship Repository

Faculty Scholarship

1987

\title{
A Lawyer's Privilege Against Self-Incrimination in Professional Disciplinary Proceedings
}

Geoffrey C. Hazard Jr.

UC Hastings College of the Law, hazardg@uchastings.edu

Cameron Beard

Follow this and additional works at: http://repository.uchastings.edu/faculty_scholarship

\section{Recommended Citation}

Geoffrey C. Hazard Jr. and Cameron Beard, A Lawyer's Privilege Against Self-Incrimination in Professional Disciplinary Proceedings, 96 Yale L.J. 1060 (1987).

Available at: http://repository.uchastings.edu/faculty_scholarship/981

This Article is brought to you for free and open access by UC Hastings Scholarship Repository. It has been accepted for inclusion in Faculty Scholarship by an authorized administrator of UC Hastings Scholarship Repository. For more information, please contact marcusc@uchastings.edu. 


\title{
Comment
}

\section{A Lawyer's Privilege Against Self- Incrimination in Professional Disciplinary Proceedings}

\author{
Geoffrey C. Hazard, Jr. $\dagger$ and Cameron Beard $+\dagger$
}

Historically, lawyer disciplinary proceedings appear to have been summary, although a full hearing generally was accorded if the lawyer contested the charge. Today, prehearing administrative inquiry usually differentiates among minor disciplinary grievances, serious but uncontested charges, and serious contested charges. In this final category, the accused has a right to a trial-type hearing. The nature of the cases that reach this stage makes it particularly likely that the one intricate procedural issue that can influence the outcome of the trial is the privilege against selfincrimination. Under the Supreme Court's interpretation of this privilege, lawyers enjoy less protection than might be supposed. Documents in their hands can generally be used against them, and in certain circumstances so can their refusal to testify. In substance, contested disciplinary proceedings are quasi-criminal. Disciplinary procedures have evolved to reflect changes in the professional community; the limited privilege available to attorneys strikes a reasonable balance between the modern lawyer's interest and those of the aggrieved party and of the public.

\section{Available Procedural Models}

In the American legal tradition there are four types of procedure upon which lawyer disciplinary proceedings could be patterned. In descending order of their protection of the private person, these are criminal

+ Sterling Professor of Law, Yale University.

It J.D., University of Connecticut, 1986. Mr. Beard did most of the research and much of the drafting for this article. Mr. Neal Wolin, Yale Law School, did additional research. The interpretations, and any errors, are Mr. Hazard's responsibility. 
procedure, civil procedure of the trial court of general jurisdiction, "some kind of hearing" of bilateral structure in the tradition of administrative law, and unilateral or dispensatory administrative justice. Criminal procedure entails eight guarantees:

-The right to notice and a statement of the charge or grievance;

-The right to present evidence and argument, including the right of cross-examination;

-The right to assistance of counsel. In modern times this has been held to include the right to publicly provided counsel for a defendant unable to afford privately retained counsel;

-The right to refuse to give self-incriminating testimony. No adverse inference may be drawn from such refusal;

-The requirement of proof beyond a reasonable doubt;

-The right to appellate review;

-The right to some measure of pretrial discovery; and

-The right to jury trial, in cases where a prison sentence may be imposed. ${ }^{1}$

Civil procedure in trial courts of general jurisdiction involves most but not all of these procedural safeguards, including the right to notice and a statement of the charge or grievance; the right to present evidence and argument; the right to assistance of counsel (but, generally speaking, no right to public provision of such assistance); the right of appeal; and the right to some measure of pretrial discovery. ${ }^{2}$ Where the proceeding is characterized as a civil action "at law," there is also a right to jury trial. Ordinarily a "preponderance of the evidence" standard applies, but in some types of civil proceedings, the charge must be established by "clear and convincing evidence."s While a civil litigant has the right to refuse to give testimony that may incriminate him in collateral criminal proceedings, it is generally held that the trier of fact may draw reasonable inferences as to the facts from the defendant's silence."

1. See generally Standards Relating to the Administration of Criminal Justice (1974); C. Whitriread, Criminal. Procedure (1980). Under the United States Constitution there is no right of appeal in state court, e.g., McKane v. Durston, 153 U.S. 684, 687-89 (1894), or for that matter in a federal court. However, the right of appeal is almost universally accorded by statute. See, e.g., 28 U.S.C. \& 1291 (1982).

2. See generally F. James \& G. Hazard, Givil Procedure (3d ed. 1985); J. Friedenthal, M. Kane \& A. Mill.er, Civil. Procedure (1985). The most significant change in civil procedure in recent times has been expansion of the right of pretrial discovery, so that in most jurisdictions litigants may obtain discovery of evidence relevant to the "subject matter" of the action regardless of admissibility. Frn. R. Crv. P. 26(b)(1).

3. For example, this includes claims involving fraud. See, e.g., Weise v. Red Owl Stores, Inc., 286 Minn. 199, 175 N.W.2d 184 (1970).

4. See generally Heidt, The Conjurer's Circle-The Fifth Amendment Privilege in Civil Cases, 91 YALE L.J. 1062 (1982). 
As one turns to administrative agency hearings, and the right to "some kind of hearing," the established requirements become much less uniform. The Supreme Court has laid down some minimal constitutional requirements for matters in which there is a right to a hearing. These include notice and a statement of the charges; the right to submit evidence and argument, if not necessarily to present it in person to the tribunal; the requirement that there be a modicum of believable evidence, although not necessarily evidence admissible under general evidentiary rules; and the right to judicial review. ${ }^{5}$ Beyond these constitutional requirements, statutes establishing various administrative proceedings generally provide, or are interpreted to require, the right of cross-examination; the right to assistance of counsel; some pretrial discovery or disclosure; proof by at least a preponderance of the evidence-and often with a requirement that the preponderance be established by technically admissible evidence; and a right to full appellate review. ${ }^{6}$ Again, there is a right to refuse to give selfincriminating testimony, ${ }^{7}$ subject to the tribunal's right to draw inferences from the party-witness's silence.

At the opposite end of the procedural spectrum from the criminal model is what might be called dispensatory justice. There is no definite pattern in this domain, for it encompasses many kinds of governmental decisionmaking. One classical type of dispensatory justice is the private legislative bill ${ }^{8}$ in seeking to obtain such a bill, the private party has no procedural rights at all, although he may be granted substantial procedural opportunities. Another example is executive clemency; there is no right to a hearing to obtain a pardon, ${ }^{\theta}$ and such hearings are rarely granted. Applicants for government contracts are sometimes given a statutory right to a hearing concerning the regularity of the competitive bidding in which they have participated, but there is generally no right to a hearing to determine the relative competence of competitors. ${ }^{10}$ On the other hand, some

5. See J. Mashaw, Due Process in the administrative State (1985); Friendly, "Some Kind of Hearing," 123 U. PA. L. REv. 1267 (1975); Redish \& Marshall, Adjudicatory Independence and the Values of Procedural Due Process, 95 YALE L.J. 455 (1986); Stewart, The Reformation of American Administrative Law, 88 HARv. L. REv. 1667 (1975). Compare Goldberg v. Kelly, 397 U.S. 254 (1970) with Perry v. Sinderman, 408 U.S. 593 (1972) and Cleveland Bd. of Educ. v. Loudermill, 470 U.S. 532 (1985).

6. See, e.g., 5 U.S.C. $\$ \$ 554-557,701-706$ (1982).

7. E.g., Spevack v. Klein, 385 U.S. 511 (1967).

8. See, e.g., Gellhorn \& Lauer, Congressional Settlement of Tort Claims Against the United States, 55 Col.um. L. Rev. 1 (1955).

9. See, e.g., Binion v. United States Dep't of Justice, 695 F.2d 1189 (9th Cir. 1983); Sullivan v. Askew, 348 So. 2d 312 (Fla. 1977); cf. Schick v. Reed, 419 U.S. 256 (1974).

10. See B.K. Instrument, Inc. v. United States, 715 F.2d 713 (2d Cir. 1983); Competition in Contracting Act of 1984, 31 U.S.C. $\$ \S 3551-3556$ (Supp. II 1986). 
franchises conferred by the government are issued by a procedure that approximates a full civil trial. ${ }^{11}$

Notwithstanding this theoretically wide range of procedural options, if one assumes that the private interest in question is sensitive enough that there should be "some kind of hearing," then under modern legal principles the range of choices is considerably narrower. A reasonably fair procedure under the circumstances would certainly include all the following:

-The right to notice and a statement of the charge or grievance;

-The right to present evidence and argument;

-The right to assistance of counsel;

-The right to appellate or judicial review;

-The right to some kind of pretrial discovery; and

-The privilege against self-incrimination.

This set of procedural standards-now generally accepted if not universally required as a matter of constitutional law-is of relatively recent origin, at least where the private interest in question could not unequivocally be called a "right." The development of these standards can, for instance, be traced in the metamorphosis of lawyer disciplinary proceedings.

\section{The Old Regime in Lawyer Disciplinary Proceedings}

Since the beginning of the nineteenth century, most American jurisdictions have required one who acts as a lawyer for others to be licensed. ${ }^{12}$ In the older parlance, and in the Hohfeldian sense, the practice of law is a "privilege," i.e., a capacity that is not an incident of citizenship but is conferred by law on a limited number of people who meet specified requirements. Law practice is a privilege in other senses as well. Properly conducted, law practice is technically and morally exacting; hence not everyone can do it properly. Lawyers also may receive and must protect privileged communications. Finally, lawyers are officers of the court, and as insiders in the system are accorded some degree of immunity from ordinary law enforcement.

The term "privilege" has long been used as a predicate in analysis of the rules governing both admission to practice and lawyer discipline. The leading treatise on law practice of the early twentieth century, Thornton's A Treatise on Attorneys at Law, stated:

The right to practice law is not a natural inherent right, but one which may be exercised only upon proof of fitness, through evidence

11. See, e.g., Office of Communication of the United Church of Christ v. FCC, 425 F.2d 543 (D.C. Cir. 1969).

12. See C. Woifram, Modern Legat. Ethtcs 825 (1986). 
of the possession of satisfactory legal attainments and fair character. The privilege of practicing law is not open to all, but is a special personal franchise limited to persons of good moral character, with special qualifications . . . ${ }^{13}$

In a 1911 case delineating the conduct necessary to warrant disbarment, one federal circuit court made a similar observation: "[T] he right to practice law," the court held, is not "a property right, to be treated with all the incidents peculiar to property," but is "merely an extraordinary privilege . . . granted . . . on certain conditions, upon the reasonable maintenance of which . . . depends . . continuance in office."14

Under traditional legal doctrine, this characterization implied that constitutional law would require only a modicum of procedural formality for revocation of an attorney's license. This is not to say that the practicing bar would have regarded dispensatory justice as meeting the proper standard of fairness, so that a license to practice law could have been terminated as readily as, say, government employment. However, the required proceedings would fall somewhere between dispensatory justice and administrative hearings on the spectrum of procedural protections. Courts certainly made it clear that disbarment proceedings were not criminal, but civil. ${ }^{15}$ Indeed, on the prevailing premise that law practice was a privilege, lawyer disciplinary procedure was structured to facilitate suspension or disbarment upon a showing of good cause. ${ }^{16}$

According to Thornton, a petition for disbarment was to set forth verified allegations specifying with reasonable particularity the misconduct for which disbarment was sought. If the court found the allegations sufficient in law, it would ordinarily issue an order against the lawyer in question, directing him to show cause why he should not be disbarred. ${ }^{17}$ The burden of proof thus was on the attorney to prove his innocence. There was little or no pretrial discovery. Appellate review was nominally available, but the tenor of the decisions suggests that a lawyer found guilty of an offense warranting disbarment had little chance of obtaining reversal on either substantive or procedural grounds. The old summary procedure is

13. 1 E. Thornton, $\Lambda$ Treatise on AtTorneys at Law 22-23 (1914).

14. In re Thatcher, 190 F. 969, 974 (C.C.N.D. Ohio 1911); see also Admission to the Bar, 13 ALBANY L.J. 142, 144 (1876) (endorsing proposals to tighten requirements for admission to bar); Admission to the Bar, 4 AlBANY L.J. 309 (1871) (criticizing ease of admission to bar as doing great injury to character and reputation of profession).

15. 2 E. ThORNTON, supra note 13 , at 1282.

16. Id. at 1281 (footnotes omitted). Thornton said that the procedural requirements for suspension or disbarment could indeed be minimal: "It is well settled that the court may summarily suspend or disbar an attorney at law for unprofessional conduct, because he is an officer thereof, providing the bounds of due process of law are not transgressed." Id. (footnotes omitted).

17. Id. at 1288-99. 
illustrated in the 1868 case of Randall $v$. Brigham, ${ }^{18}$ in which the court imposing the sanction was apprised of the lawyer's wrong-doing by a letter from the client which, when not disputed by the lawyer, was relied on by the court as a sufficient basis for an immediate order of disbarment. A similar flavor is captured in the more modern case of In re Ruffalo, ${ }^{19}$ in which the Court of Appeals for the Sixth Circuit, sitting as a disciplinary committee, focused on one set of charges and then, after a somewhat casual proceeding, disbarred on another.

\section{Modern Disciplinary Procedure}

By the 1960's, the old style lawyer disciplinary procedure had begun to disappear. In re Ruffalo, ${ }^{20}$ decided in 1968, established as a minimum constitutional requirement that notice of charges be given and that the evidence be within the scope of the charge. The Supreme Court had laid the groundwork for this decision some years before in cases imposing requirements of minimum rationality on refusals of admission to practice. ${ }^{21}$ In the early 1960's, the Supreme Court also decided a variety of cases involving lawyers' "solicitation" that further extended constitutional limitations on the imposition of disciplinary sanctions on lawyers. ${ }^{22}$ In the same period, as we shall note below, the Court started to move in directions that would have imposed important constitutional limitations on the adverse consequences that could follow invocation of the privilege against self-incrimination in lawyer disciplinary proceedings. State appellate courts also manifested greater concern for procedural fairness in such proceedings, particularly with respect to the sufficiency of evidence where serious misconduct was charged..$^{23}$ By the middle of the 1960's, if not before, summary procedure, in which the accused lawyer was required to "show cause" why he should not be disbarred, was obsolete.

The development of lawyer disciplinary procedure since then seems to find its motive force in two disparate legal movements. One is the introduction of more elaborate procedure through adoption of legislation and rules of court at the state level. The other is the retraction by the Supreme Court of some previously announced or implied constitutional procedural protections concerning self-incrimination. ${ }^{24}$

\footnotetext{
18. 74 U.S. (7 Wall.) 523 (1868).

19. 370 F.2d 447 (6th Cir. 1966), rev'd, 390 U.S. 544 (1968).

20. 390 U.S. 544 (1968).

21. See Konigsberg v. State Bar, 353 U.S. 252 (1957); Schware v. Board of Bar Examiners, 353 U.S. 232 (1957).

22. See Brotherhood of R.R. Trainmen v. Virginia ex rel. Virginia State Bar, 377 U.S. 1 (1964); NAACP v. Button, 371 U.S. 415 (1963).

23. See, e.g., In re Hallinan, 43 Cal. 2d 243, 272 P 2d 768 (1954).

24. See infra text accompanying notes $66-76$.
} 
Professor Charles Wolfram's excellent new treatise on legal ethics usefully summarizes the procedural system emerging in state rules and statutes:

The states follow several different variations, but a commonly employed model begins with an informal administrative proceeding to determine whether the matter should be dismissed or disposed of with a nondisciplinary admonition or, instead, whether there is reason to conclude that a serious violation, requiring a full hearing, has probably occurred. Any hearing is conducted before an administrative panel with the lawyer having a right to a rehearing before the full administrative board and a final right to review on the record in an appellate court. $^{25}$

This model is essentially that of civil procedure of the trial court, with three significant variations. First, there is a required screening by the disciplinary agency to determine whether lodging a formal charge would be warranted. Functionally, this resembles the probable cause hearing in criminal procedure. It screens out those complaints for which the evidence is insufficient to get to a trier of fact, and synthesizes the evidence when it meets the sufficiency test, in the latter case laying the foundation for possible "plea bargaining." The second variation from the civil procedure model concerns discovery. In some jurisdictions, the accused lawyer has the same rights of discovery as are available in civil actions in the trial court of general jurisdiction, ${ }^{26}$ but the prevailing pattern gives the accused only informal access to the prosecution's dossier. ${ }^{27}$ Third, except in Texas and Georgia, there is no right to a jury trial. ${ }^{28}$

The prevailing model thus may be described as a relatively formal version of administrative law procedure. Its elements include:

-The benefit of pre-charge screening by the disciplinary enforcement agency; ${ }^{29}$

-The right to notice and a statement of the charge or grievance; ${ }^{30}$

-The right to formal or informal discovery, ${ }^{31}$

-The right to assistance of counsel; ${ }^{32}$

-The rights to subpoena witnesses and evidence, to cross-examine ad-

25. C. WOL.FRAM, supra note 12, at 99 (footnote omitted); see also STANDARDS FOR LAWYER Discipline and Disabilitry Prockerdings (1979) [hereinafter 1979 ABA Standards].

26. See, e.g., Cal.. Bus. \& Prof. Code $\S 6085$ (West 1974).

27. See 1979 AB $\Lambda$ STANDARDS, supra note $25, \S 8.29$.

28. C. Wol.fram, supra note 12 , at 99.

29. 1979 ABA STANDARDS, supra note 25 , \$§ 8.4-.6.

30. Id. $\S 8.23$.

31. Id. $\S 8.29$.

32. Id. $\S 8.34$. 
verse witnesses, and to exclude evidence inadmissible under the rules of evidence; ${ }^{3 s}$

-The requirement of proof by a preponderance of the evidence or, in some cases, by clear and convincing evidence; ${ }^{34}$ and

-The right to judicial review. ${ }^{35}$

The large majority of lawyer disciplinary matters do not go the entire route, however, or even beyond the stage of informal investigation. Two sets of circumstances contribute to this phenomenon. First, most grievances are essentially minor contract or performance disputes-charges of inattention, excessive fees, inadequate results-or semi-paranoiac and fully paranoiac grievances about justice gone wrong. At the stage of informal investigation the disciplinary agency rejects the complaints that appear to be baseless and mediates the minor ones that appear to have merit.

The common account among professionals in the field, and the available statistics, indicate that this pattern of screening through administrative review operates in all jurisdictions. There are no uniformly recognized categories of stages of the disciplinary process, and for this reason there are also no nationally recognized procedural statistics with respect to disciplinary matters. The available statistics are therefore not fully comparable from jurisdiction to jurisdiction or year to year. Nevertheless, there is a general pattern, in which the ratio of "complaints received" to "number of lawyers formally charged" ranges from around 15:1 (for example, Florida) to around 30:1 (for example, Tennessee). ${ }^{36}$

The second factor reducing the number of grievances that reach the hearing stage is the likelihood that cases involving negligence or incompetence serious enough to impel formal legal recourse will find such recourse outside the disciplinary system. Generally it is not worthwhile to the complainant to pursue the disciplinary route in a case of serious malpractice because the payoff to the injured party will be only psychic. The complainant is better off bringing a civil action for malpractice, where the lawyer's behavior can be assessed by a jury and her assets and liability insurance can be reached for compensation.

Since petty cases and serious negligence cases are shunted off in these ways, the remaining disciplinary cases typically are ones that involve fraud, misappropriation, bribery, tax evasion, or other opprobrious (and

\footnotetext{
33. Id. $\S \S 8.32,8.35,8.36$.

34. C. Wol.fram, supra note 12 , at 108-10. At least one state, Georgia, employs the "beyond a reasonable doubt" standard. Id. at 109 n.36.

35. C. Wolfram, supra note 12, at 111-14.

36. The only source of data on disciplinary proceedings is the annual Survey on Lawyer Discipline Systems, compiled by the American Bar Association Standing Committee on Professional Discipline and Center for Professional Responsibility. The survey shows the following for a group of more or less representative states:
} 
usually illegal) behavior. Moreover, in cases that go to disciplinary trial there often is, or has been, or may be, a parallel criminal investigation. And for this reason in turn, the increasingly formal character of procedure in these hearings and, in particular, the rules governing selfincrimination, appear to be central to most major disciplinary proceedings.

\section{Self-Incrimination in Lawyer Disciplinary Proceedings}

A contested disciplinary hearing thus can involve not only professional misconduct, sanctionable by disbarment or lesser penalty, but also a criminal offense. A simple example is a charge that a lawyer misappropriated a client's funds, an act that would constitute both professional misconduct and the crime of theft. Another example is fraud against a third party, which is professional misconduct and in most circumstances would also involve the crime of mail fraud. ${ }^{37}$ In a proceeding involving such charges, the testimony of the lawyer, or evidence consisting of documents in his possession, can be prime relevant evidence. The key legal question is how far such testimony and evidence are protected by the privilege against selfincrimination.

\section{A. Privilege Not To Testify}

The privilege of refusing to testify against one's self in a criminal case, conferred by the Fifth Amendment, applies by virtue of the Fourteenth

\begin{tabular}{|c|c|c|c|c|}
\hline \multicolumn{5}{|c|}{ TABLE ONE } \\
\hline & $\begin{array}{c}\Lambda \\
\text { Number } \\
\text { of Resident } \\
\text { Lawyers }\end{array}$ & $\begin{array}{c}\text { B } \\
\text { Estimated } \\
\text { Complaints } \\
\text { Received by } \\
\text { Agency }\end{array}$ & $\begin{array}{c}\text { C } \\
\text { Complaints } \\
\text { Resulting } \\
\text { in Finding } \\
\text { of Probable } \\
\text { Cause }\end{array}$ & $\begin{array}{c}\text { D } \\
\text { Number of } \\
\text { Lawyers } \\
\text { Formally } \\
\text { Charged }\end{array}$ \\
\hline Arizona & $\begin{array}{l}\text { 7,493 } \\
\text { ratio: }\end{array}$ & $\begin{array}{c}1,976 \\
\Lambda / B=3.3: 1\end{array}$ & $\begin{array}{c}242 \\
B / C=8: 1\end{array}$ & $\stackrel{51}{B / D=39: 1}$ \\
\hline Florida & 27,164 & $\begin{array}{c}6,268 \\
4.3: 1\end{array}$ & $\begin{array}{c}390 \\
16: 1\end{array}$ & $\begin{array}{c}12 \\
16: 1\end{array}$ \\
\hline Illinois & 42,357 & $\begin{array}{c}4,779 \\
8.9: 1\end{array}$ & $\begin{array}{c}184 \\
26: 1\end{array}$ & $\begin{array}{l}184 \\
26: 1\end{array}$ \\
\hline Massachusetts & 24,691 & $\begin{array}{c}1,524 \\
16: 1\end{array}$ & $\begin{array}{c}94 \\
16: 1\end{array}$ & $\begin{array}{c}94 \\
16: 1\end{array}$ \\
\hline Minnesota & 13,184 & $\begin{array}{c}1,244 \\
11: 1\end{array}$ & $\begin{array}{l}251 \\
5: 1\end{array}$ & $\begin{array}{c}50 \\
25: 1\end{array}$ \\
\hline Tennessee & 9,676 & $\begin{array}{l}715 \\
14: 1\end{array}$ & $\begin{array}{c}157 \\
4.6: 1\end{array}$ & $\begin{array}{c}26 \\
28: 1\end{array}$ \\
\hline
\end{tabular}

Source: ABA Centter for Profissional. Responsibility \& ABA Standing Comm. on Professional. Discipline, SURvey on Lawyer Discipline Systems, Chart I (1986).

37. See 18 U.S.C. \$§ 1341, 1343 (1982). Indeed, the Second Circuit has gone so far as to hold that a lawyer's concealed conflict of interest can constitute mail fraud. United States v. Bronston, 658 F.2d 920 (2d Cir. 1981). 
Amendment to proceedings in state tribunals. ${ }^{38}$ The privilege applies both where the testimony is sought in a criminal proceeding and where the testimony is sought in a non-criminal proceeding but reveals conduct that is a crime; such testimony which reveals a crime might later be used in a criminal proceeding against the witness. ${ }^{39}$ It is settled that lawyer disciplinary proceedings are among the proceedings in which the privilege applies. ${ }^{10}$ Hence, a lawyer may refuse in a disciplinary proceeding to give testimony that tends to show that he has committed a crime.

To protect the privilege, the Supreme Court has ruled that no adverse consequence such as disbarment can be imposed for the act of invoking the privilege. ${ }^{41} \mathrm{~A}$ further and more difficult question is whether an adverse inference of fact may be drawn from the refusal to testify. Whether such an inference is permissible has not been settled under the Fourteenth Amendment, but rather depends on state law. In turn, the state rule is determined by whether the state, by statute or common law, characterizes disciplinary proceedings as criminal or quasi-criminal, on the one hand, or civil, on the other. Most states regard disciplinary proceedings as quasi-criminal and consequently disallow an adverse inference where a defendant has invoked the privilege against self-incrimination. ${ }^{42}$ Some courts, however, consider disciplinary proceedings to be civil in nature for almost all purposes, and therefore allow an adverse inference to be drawn even where the defendant has invoked the privilege. ${ }^{43}$

\section{B. Immunity}

If no adverse inferences can be drawn and if the disciplinary authority cannot by other evidence prove the facts showing professional misconduct, the prosecution fails unless evidence can be obtained from the lawyer herself. One escape for the disciplinary prosecutor is to arrange immunity for the lawyer against subsequent criminal prosecution. Transactional immunity bars prosecution for any crime included in the transaction to which the testimony pertains. To confer transactional immunity is therefore to insulate the lawyer from any criminal prosecution for the matters to be covered by her testimony. Under the constitutional law of some states,

38. Malloy v. Hogan, 378 U.S. 1, 3 (1964).

39. Id. at 11; Lefkowitz v. Cunningham, 431 U.S. 801, 804-05 (1977).

40. Spevack v. Klein, 385 U.S. 511 (1967).

41. Id. at 516.

42. See, e.g., State Bar v. Woll, 387 Mich. 154, 194 N.W.2d 835 (1972); In re Silverberg, 459 Pa. 107, 327 A.2d 106 (1974). Where the attorney refuses to testify or to answer the original complaint, but does not do so on the grounds of privilege, however, most courts will treat the proceeding as civil and allow adverse inferences to be drawn. See, e.g., In re Randel, 158 N.Y. 216, 52 N.E. 1106

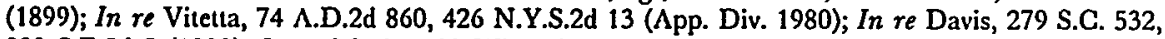
309 S.E.2d 5 (1983); In re Marine, 82 Wis. 2d 612, 264 N.W.2d 290 (1978).

43. State v. Postorino, 53 Wis. 2d 412, 193 N.W.2d 1 (1972). 
transactional immunity is required before testimony can be compelled. ${ }^{44}$ The Supreme Court has held that the Fourteenth Amendment requires only use immunity. ${ }^{45} \mathrm{~A}$ lawyer-witness who is given use immunity can be compelled to give self-incriminating testimony so long as that testimony, and other evidence to which it may lead, is not used against him in any later criminal proceeding. A subsequent prosecution, however, can be based on independently derived evidence. ${ }^{46}$

Ordinarily, only the prosecutor can confer, or request that a court confer, criminal immunity. ${ }^{47}$ Hence, the professional disciplinary authority depends on the cooperation of the prosecutor in this respect.

Assuming that the lawyer-witness is given the required immunity regarding subsequent criminal prosecution, the next question is whether his testimony can be compelled for use against him in the disciplinary proceeding. Put differently, is the penalty that might be imposed in the disciplinary proceeding itself a "crime," about which the lawyer may refuse to testify even where he has been given the requisite immunity against further criminal prosecution? The prevailing view is that professional sanctions and proceedings are not criminal for this purpose. ${ }^{48}$ Hence, a lawyer who has been given the requisite immunity against criminal prosecution has an obligation to answer questions about his professional conduct even though doing so may render him guilty of professional misconduct. ${ }^{49}$ Sanctions for refusal to comply with this obligation include contempt. ${ }^{50}$ The disciplinary tribunal may also draw adverse inferences as to the facts, on the familiar evidentiary rule that an adverse inference may be drawn from refusal to produce evidence if withholding is not privileged. ${ }^{31}$

44. See, e.g., In re Anonymous Attorneys, 41 N.Y.2d 506, 509-10, 362 N.E.2d 592, 595-96, 393 N.Y.S.2d 961, 964 (1977).

45. See Zicarelli v. New Jersey State Comm'n of Investigation, 406 U.S. 472 (1970); Kastigar v. United States, 406 U.S. 441 (1970).

46. Kastigar, 406 U.S. at 457; Murphy v. Waterfront Comm'n, 378 U.S. 52, 79 n.18 (1964).

47. See Note, Prospective Determinations of Derived Use in Civil Proceedings: Upsetting the Immunity Balance, 50 FordHAM L. REv. 989, 990, 997-98 (1982).

48. See In re Daley, 549 F.2d 469, 475 (7th Cir. 1977); Segretti v. State Bar, 15 Cal. 3d 878, 886, 544 P.2d 929, 933, 126 Cal. Rptr. 793, 797 (1976); In re March, 71 Ill. 2d 382, 395, 376 N.E.2d 213, 218 (1978); Maryland State Bar Ass'n v. Sugarman, 273 Md. 306, 318-19, 329 A.2d 1, 7 (1974); In re Connaghan, 613 S.W.2d 626, 631 (Mo. 1981) (en banc); Anonymous Attorneys v. Bar Ass'n of Erie County, 41 N.Y.2d 506, 510-11, 362 N.E.2d 592, 595, 393 N.Y.S.2d 961, 963-64 (1977); Committee on Legal Ethics of the W. Va. State Bar v. Graziani, 157 W. Va. 167, 170-72, 200 S.E.2d 353, 355 (1973). See generally Annotation, Use in Disbarment Proceeding of Testimony Given by Attorney in Criminal Proceeding Under Grant of Immunity, 62 A.L.R.3d 1145 (1975); C. WolfraM, supra note 12, at 99.

49. See In re March, 71 Ill. 2d 382, 398, 376 N.E.2d 213, 220 (1978); see also Comment, The Privilege Against Self-Incrimination in Bar Disciplinary Proceedings: What Ever Happened to Spevack?, 23 VILL. L. REv. 127 (1977).

50. See Anonymous Attorneys v. Bar Ass'n of Erie County, 41 N.Y.2d 506, 362 N.E.2d 592, 393

N.Y.S.2d 961 (1977). See generally Florida Bar v. Doe, 384 So. 2d 30 (Fla. 1980); Minnesota State

Bar Ass'n v. Divorce Assistance Ass'n, 311 Minn. 276, 248 N.W.2d 733 (1976).

51. See Heidt, supra note 4, at 1108-09. 
Although testimony given in a disciplinary proceeding under a grant of immunity may be used as evidence against the attorney concerning the pending charges, it is questionable whether such testimony could support new charges not part of the original complaint. In re Ruffalo ${ }^{52}$ indicates that a defendant is entitled to adequate notice of the charges against him, and many courts will find error where the complaint against an attorney has been substantially amended during the proceedings. ${ }^{53}$ On this basis, the institution of a subsequent action against the attorney might be necessary. However, not all courts follow this strict approach. ${ }^{54}$

Again assuming that the requisite immunity has been granted, it would also seem that the lawyer could be disbarred or otherwise professionally disciplined for refusing to answer questions. Many states will find that it is professional misconduct to refuse to respond to a valid disciplinary inquiry. ${ }^{65}$ If such a disciplinary inquiry is not interdicted by constitutional privilege, it is valid; and if immunity has been granted, there is no constitutional privilege. The refusal to respond in these circumstances is therefore itself professional misconduct. ${ }^{58}$ On the basis of DR $1-102,{ }^{87}$ however, some courts have held that it is not a disciplinary violation to refuse to respond to inquiries. ${ }^{58}$

That a lawyer must respond to inquiries may seem to conflict with the rule that a lawyer's invocation of the self-incrimination privilege cannot be a basis for disbarment or other professional sanction. ${ }^{59} \mathrm{~A}$ corollary to this privilege is that a lawyer may not be required to choose between relinquishing the privilege and automatically suffering professional discipline. ${ }^{60}$ However, where the lawyer claims the privilege and is then granted the requisite immunity, she has obtained the benefits of the privilege. The privilege protects against incrimination by one's own testimony,

52. 390 U.S. 544 (1968).

53. See, e.g., Committee on Professional Ethics and Grievances of the Virgin Islands v. Johnson, 447 F.2d 169, 173 (3d Cir. 1971); In re Conduct of Chambers, 292 Or. 670, 676, 642 P.2d 286, 291 (1982).

54. See State v. Caenen, 235 Kan. 451, 460, 681 P.2d 639, 644 (1984) (due process imposes no strict requirements for setting forth allegations); State ex rel. Nebraska State Bar Ass'n v. Leonard, 212 Neb. 379, 383, 322 N.W.2d 794, 796 (1982) (disciplinary proceeding is not lawsuit with formalities of pleading; "technicalities" may not be invoked to defend charges).

55. See Modia. Rul.es of Profrasional. Conduetr Rule 8.1(b) (1981); Model Code of ProFESSIONAI. RrSPONSIBILITY DR 1-102(A)(5), 1-102(A)(6) (1981); see also In re Serstock, 316 N.W.2d 559, 560-62 (Minn. 1982) (refusal to cooperate with ethics committee one of grounds warranting disbarment).

56. See In re March, 71 Ill. 2d 382, 400, 376 N.E.2d 213, 220 (1978).

57. Modei. CoDE of Profrssional. Rrsponsibil.try DR 1-102 (1981).

58. See, e.g., In re Geurts, 290 Or. 241, 247-48, 620 P.2d 1373, 1376 (1980) (failure to respond to bar's inquiries not grounds for discipline). See generally Annotation, Failure to Co-operate with or Obey Disciplinary Authorities as Ground for Disciplining Attorney-Modern Cases, 37 A.L.R.4th 646 (1985).

59. See Spevack v. Klein, 385 U.S. 511, 514-16 (1967).

60. See Gardner v. Broderick, 392 U.S. 273,279 (1968). 
not against loss of a valuable right or status resulting from such testimony. There is an anomaly, if not a contradiction, in holding that disciplinary proceedings are sufficiently "criminal" to preclude drawing adverse inferences from the accused's invocation of the privilege against selfincrimination, ${ }^{81}$ while also holding that they are sufficiently not "criminal" that disbarment may be imposed despite the accused's receipt of immunity. The effect of adhering to both propositions is that the grounds for discipline must be established either by independent evidence, or by the lawyer's testimony compelled by removing the risk that it will send him to jail. That conclusion is not unreasonable, however awkward the premises from which it is derived.

\section{Protection of Records}

In the absence of constitutional privilege, a lawyer in a disciplinary proceeding has a duty to comply with a subpoena or equivalent demand for the production of documents concerning his professional conduct. ${ }^{82}$ How does the privilege against self-incrimination operate where the documents tend to prove conduct constituting a crime on the part of the lawyer?

In Boyd v. United States, decided in 1886, the Supreme Court held that the act of producing documents was the equivalent of giving testimony. On this premise, a person could not be compelled to respond to a subpoena to produce documents that incriminated him. ${ }^{63}$ Various exceptions to the Boyd rule were developed. For example, a person could be compelled to produce someone else's documents in his possession, even if they incriminated the individual producing them. Thus, a corporate officer could be compelled to produce incriminating corporate records. ${ }^{64}$ Furthermore, the "required records" exception held that if the records in question were required by law to be maintained, their production was required notwithstanding their incriminating character. ${ }^{85}$

For a time, the Supreme Court seemed to be going in the direction of expanding Boyd. ${ }^{68}$ This trend was short-lived. In Couch v. United

61. See supra text accompanying note 41.

62. See Memphis \& Shelby County Bar Ass'n v. Vicks, 40 Tenn. App. 206, 214, 290 S.W.2d 871, 875 (1955), citing People ex rel Karlin v. Culkin, 248 N.Y. 465, 162 N.E. 487 (1928).

63. Boyd v. United States, 116 U.S. 616 (1886); Heller v. United States, 104 F.2d 446 (4th Cir. 1939).

64. Davis v. United States, 328 U.S. 582 (1946); Wilson v. United States, 221 U.S. 361 (1911).

65. Shapiro v. United States, 335 U.S. 1 (1948).

66. See Marchetti v. United States, 390 U.S. 39 (1968) (three-part test for determining what constitutes legitimate "required" records); Spevack v. Klein, 385 U.S. 511, 515 (1967); Albertson v. Subversive Activities Control Bd., 382 U.S. 70 (1965) (not all records can be required by law to be kept). 
States $^{\text {B7 }}$ the Court held that the Fifth Amendment privilege is personal, protecting only against one's having to tender self-incriminating evidence. On this basis, the Court held that when records had been turned over to an accountant they were outside of the "private enclave" and not protected. Similarly, in Bellis v. United States, ${ }^{68}$ the Court held that an attorney could not claim privilege for records of a dissolved law firm because the privilege is personal and hence not applicable to the records of a collective entity.

Application of the Fifth Amendment privilege to documents, whatever their character or location, was significantly undermined in Fisher $v$. United States. ${ }^{69}$ There the Court held that Fisher's tax records, prepared by his accountant but in the possession of his attorney, were not privileged. The original preparation of the documents was a voluntary act, not "compelled"; the production of the documents was not the giving of testimony. Hence the production of the documents was not protected by the Fifth Amendment. "The taxpayer's privilege under [the Fifth] Amendment is not violated by enforcement of the summonses involved in these cases because enforcement against a taxpayer's lawyer would not 'compel' the taxpayer to do anything-and certainly would not compel him to be a 'witness' against himself."'70

Inquiry next shifted to whether the production of documents was an act equivalent to giving testimony, even if the contents of the documents were not privileged. ${ }^{71}$ In United States $v$. Doe, ${ }^{72}$ the Gourt held that the fact that the contents of documents tended to incriminate the producer did not make them privileged, following Fisher in the proposition that information committed to documents is not testimony. ${ }^{73}$ Doe recognized, however, that the act of producing a document could be an affirmation of the document's authenticity and hence equivalent to testimony. The court went on to say, however, that use immunity could be given as to that act. ${ }^{74}$ Hence, a lawyer can be compelled to produce documents without a grant of immunity as to their contents, so long as immunity is granted against use of

67. 409 U.S. 322 (1973).

68. 417 U.S. 85 (1974).

69. 425 U.S. 391 (1976).

70. Id. at 397 .

71. See Andresen v. Maryland, 427 U.S. 463 (1976) (attorney's records seized in valid search and seizure not privileged because attorney was not "compelled" to produce the documents himself). See generally Note, In re Doe: Required Records and the Fifth Amendment, 16 CoNN. L. REv. 1021 (1984) (discussing Fifth $\Lambda$ mendment as it affects compelled production of documents); Comment, Constitutional Law: Privilege Against Self-Incrimination Denied as to Documents Recovered by Taxpayer from His Accountant and Transferred to His Attorney, 59 MiNN. L. REv. 751 (1975).

72. 465 U.S. 605 (1984).

73. Id. at 612 .

74. Id. at 612-17. 
the act of production to authenticate them. ${ }^{75}$ If the documents can be independently authenticated, for example by a client or by the lawyer's secretary or associate, then the documents can be presented in evidence in a disciplinary proceeding. ${ }^{26}$

\section{Concluding Reflections}

In an earlier day, a disciplinary proceeding was something like an ouster from a fraternity. Membership in the bar was considered a privilege; abuse of the privilege in the form of serious misbehavior was considered a ground for its termination; and the fraternity understood that a charge of such misbehavior would be brought only if it could be proved. Prosecution of charges was therefore generally summary, and procedural safeguards correspondingly limited. That is, the real and vital normative controls were within the profession as a social group and included such "informal" sanctions as disapprobation, imputation of bad reputation, and denial of usual professional courtesies. Disciplinary proceedings operated as a final and formal memorialization of an informal but effective verdict already reached by professional peers.

Since those days the structure of the profession has changed in the localities in which most lawyers practice. Some lawyers still practice in the old setting-small cities with a relatively small bar of mostly general practitioners who know each other and each other's technical and ethical capabilities and limitations ${ }^{77}$ - but the large majority of lawyers practice in an impersonal professional cosmopolis. There are literally thousands of lawyers within the daily work radius of most contemporary practicing lawyers. Inside the professional cosmopolis the members are separated from each other into professional "neighborhoods" by specialization and subspecialization, status stratification, and the enclosures of firms, corporate law departments, government offices, and legal service agencies. ${ }^{78}$ There is a professional community only in name. The older social controls, based on first hand acquaintance with personalities, reliable gossip,

75. Id. at 617 n.17.

76. See In re Grand Jury Proceedings, 727 F.2d 941, 945 (10th Cir.) (attorney held in contempt for refusing to produce client files that would tend to incriminate attorney; such files were held for client by attorney in representational capacity, and their production by attorney was therefore unprotected by privilege), cert. denied, 469 U.S. 819 (1984); Florida Bar v. White, 384 So. 2d 1266 (Fla. 1980) (attorney compelled, without grant of immunity, to produce records of his trust account); In re Zisook, 88 Ill. 2d 321, 430 N.E.2d 1037 (1981) (attorney members of professional corporation could not invoke Fifth Amendment protection for documents in his possession belonging to corporate entity); Note, Abolition of Fifth Amendment Protection for the Contents of Preexisting Documents: United States v. Doe, 38 Sw. L.J. 1023 (1984).

77. See generally M. Handler, The Lawyer and His Communrty (1967); Landon, Clients, Colleagues, and Community: The Shaping of Zealous Advocacy in Country Law Practice, 1985 AM. B. Found. Ris. J. 81.

78. See generally J. Heinz \& E. Lauman, Ghicago Lawymss (1982). 
and continual professional interaction, have become both ineffective and intolerable-ineffective because there is no face-to-face professional community having a shared awareness of who are the deviants, and intolerable because imposing sanctions informally without real informal knowledge is bound to result in arbitrary and discriminatory enforcement.

Lawyers have thus become a more or less faceless vocational category, membership in which can be clearly identified only by reference to the system of official licensure. The transformation occurred at different rates in different places, beginning with such large cities as New York, Los Angeles, and Chicago. It has accelerated with the rapid increase in the number of lawyers since the 1950's, such that the bar has more than doubled in size in one professional generation. ${ }^{79}$ The profession's consciousness of the change has of course lagged behind the change itself. Even now the profession has difficulty recognizing that it is qualitatively and irreversibly different from what it used to be. ${ }^{80}$

Nevertheless, the nature of modern disciplinary process bears the unmistakable imprint of this transformation. Disciplinary proceedings no longer legally confirm antecedent informal judgments by professional peers; they are instead a formal legal method by which the judgments themselves are made on behalf of the profession. This is reflected in the legal concept of disciplinary proceeding that gained rising currency from the 1950's onward: The license to practice law is now recognized as, if not a right in all respects, certainly a valuable personal interest, and as such is subject to termination only upon substantial proof established through procedures meeting standards of fundamental fairness. Behind this changed view one can discern recognition that the bar could no longer be treated as the closed fraternity that it once imagined itself to be. In any event, since the mid-1960's, lawyer disciplinary procedure in most jurisdictions has been well on its way to full formalization. In the mid-1960's the Supreme Court appeared to be on its way to constitutionalizing lawyer disciplinary procedure, just as it was constitutionalizing criminal procedure.

What has happened since is a two-fold turn of events. On the one hand,

79. See B. Curran, K. Rosich, C. Carson \& M. Puccetti, The Lawyer Statistical RePORT (1985), Table 1.1.1, p.4:

\begin{tabular}{lc} 
Year & Lawyer Population \\
\hline 1951 & 221,605 \\
1960 & 285,933 \\
1970 & 355,242 \\
1980 & 542,205 \\
1985 & $675,000^{*}$ \\
& $*$ estimated
\end{tabular}

80. See american Bar ass'n Comm'n on Professionalism, “. . . In the Spirit of Public Service:" A Blueprint for the Rekindling of LaW Professionalism 1-11 (1986). 
the legal profession itself has come to consider disciplinary proceedings to require great formality. If anything, the procedural protections now commonly provided in such proceedings-particularly the right to informal screening, and in many states, the right to have at least the preliminary inquiry conducted in private ${ }^{81}$-exceed those in normal civil litigation. At the same time, the Supreme Court has declined to impose an extensive due process jurisprudence on lawyer disciplinary proceedings. Most important has been the Court's refusal to treat disciplinary proceedings as criminal and its limitation of the effective scope of the privilege against self-incrimination. In disciplinary proceedings today a lawyer cannot be suspended or disbarred unless a substantial case is made out against her through admissible evidence, and she cannot be made to testify against herself. However, a lawyer is subject to conviction on the basis of her papers, a potentially rich source of incriminating evidence. Given the disappearance of the traditional sources of information about a lawyer's behavior-the collective informal perception of professional peers-documentary sources usually are about all there is on which to establish a case. Thus, the somewhat convoluted development of the legal doctrine concerning the availability of the privilege against selfincrimination appears to have responded appropriately to changes in the structure of the legal profession and the significance of lawyer disciplinary hearings.

81. See 1979 ABA STANDARdS, supra note $25, \S 8.24$. 